\title{
JUDICIAL ACCELERATION OF THE ADMINISTRATIVE PROCESS: THE RIGHT TO RELIEF FROM UNDULY PROTRACTED PROCEEDINGS*
}

A RECENT decision of the Fourth Circuit Court of Appeals, upholding in part a district court order enjoining the Regional Director of the National Labor Relations Board from proceeding with certain further hearings ordered by the NLRB, raises the problem whether unduly protracted hearings warrant immediate judicial review notwithstanding the general policy of jutdicial nonintervention during the course of administrative proceedings. This case, $D c t r-$ ing Milliken, Inc. v. Johnston, ${ }^{1}$ dramatizes a frequently criticized aspect of the administrative process: the slow, cumbersome, and costly manner in which cases are adjudicated. ${ }^{2}$ Ironically, the desire to achieve an efficient and prompt enforcement of many of our laws was a major motive for extending the scope of the administrative process. ${ }^{3}$ Despite this objective, it is almost universally acknowledged that excessive delay is a striking characteristic of administrative proceedings today. As Judge Prettyman has stated, "[Presently] the American businessman or labor leader ... [is putting up] with processes which do not function with the accuracy and expedition which he requires for his working purposes. ..." The hardships of such delay on parties to administrative proceedings have frequently been demonstrated. ${ }^{5}$ But many instances of delay, re-

*Deering Milliken, Inc. v. Johnston, 295 F.2d 856 (4th Cir. 1961).

1. 295 F.2d 856 (4th Cir. 1961).

2. Prettyman, Reducing the Delay in Administrative Hcarings, 39 A.B.A.J. 966 (1953). With this delay has come an increased loss of confidence in, and an increase in public apprehension toward, administrative government. With only few exceptions, a party to an administrative proceeding has no assurance that he will receive that degree of justice in accordance with law which he expects and usually receives from the courts. See Oulahan, Reforming the Administrative Process: A Challenge to the American Bar, 51 Buef 101 (1956).

3. James M. Landis, a former dean of the Harvard Law School who served as a member of the Federal Trade Commission and Chairman of the Civil Aeronautics Board, observed that the hope and confidence which initially surrounded the administrative process anticipated that "it would supplant in some respect the costliness [and delay] of litigation in our courts." Landis, The Administrative Process: The Third Decade, 47 A.B.A.J. 135, 138 (1961). See also an address of Stuart Rothman, General Counsel of the NLRB, in which he stated:

[O]ne of the principle [sic] reasons the administration of certain laws was taken from the courts and placed in the hands of . . . administrative agencies . . . was because the processes of the courts had become too cumbersome and time consuning. . . . Address by Stuart Rothman, "Time and Tide in Taft-Hartley," Jan. 8, 1960, reported in 45 L.R.R.M. 86, 89 (1960).

4. Judge Prettyman goes on to comment that not only will these groups not put tup with such delay-waiting years for a decision which could be reached in weeks-but will also not "indefinitely permit disputed issues to be buried in an ocean sand of irrelevancies and thus lost instead of being decided." Prettyman, supra note 2, at 966.

5. See Oulahan, supra note 2. 
gardless of its effects on the parties, are not susceptible to judicial solution. Thus, for instance, crowded dockets resulting from inadequate appropriations and a lack of personnel demand solutions uniquely available to the Congress or the agencies themselves. ${ }^{6}$ Courts may, however, deal with certain causes of delay by enjoining or requiring an administrative decision. ${ }^{\top}$ Thus, courts can be responsive to the excessive admission of evidence in a particular case or to an unreasonable refusal by an agency to decide a case before it. ${ }^{8}$ However, judicial relief from the burdens of delay, whatever the cause of such delny, necessarily presupposes intervention in administrative proceedings before the administrative process has fully run its course.

The controversy in Deering Milliken began when Darlington discontinued its operations, discharged its employees, and went into liquidation ${ }^{\circ}$ immediately after the Textile Workers Union of America (TIVUA) received a majority of the employees' votes in a representative election at the Darlington Manufacturing Company. Hearings began in January 1957 on the Union's charge against Darlington that the shutdown constituted an unfair labor practice $;^{10}$ at these hearings the Union sought to present evidence to establish that Darlington's operation, including its labor relations policy, was controlled by Deering Milliken, Darlington's sales representative, and that, therefore, Deering Milliken should be held responsible for the alleged unfair labor practice."11 This evidence was rejected as outside the scope of the complaint, and after several months of hearings, the Trial Examiner concluded that Darlington had committed unfair labor practices. ${ }^{12}$ Since Darlington's cessation of business was in part attributable to economic motives, the Examiner recommended that the Board's order not contain the traditional remedy requiring reinstatement and reimbursement of lost wages. ${ }^{13}$ On review, the Board remanded the case and

6. Many agencies have attempted to correct their internal problems themsclves. According to Philip Elman, Federal Trade Commissioner, "the administrative agencies are [presently] engaged in critical self-appraisal and internal reform. ... [T]ask forces and ad hoc committees are busily drafting reorganization plans, revising rules of practice, streamlining procedures, etc." Address by Commissioner Elman, Federal Bar Association Annual Convention, Sept. 13, 1961.

7. See note 49 infra and accompanying text.

8. Landis, stpra note 3 , at 139 .

9. Brief for Appellant, p. 3, Deering Mfilliken, Inc. v. Johnston, 295 F.2d 856 (4th Cir. 1961).

10. The unfair labor charge was brought pursuant to $\$ \$ 8(a)(1),(3)$ and (5) of the NLRA on the basis that Darlington had closed its mill and gone into liquidation "in order to discourage union membership and to evade its obligation to bargain with the Union. ..." Id. at 4.

11. 295 F.2d 856, 858 (4th Cir. 1961).

12. Ibid.

13. Brief for Appellant, p. 4, Deering Milliken, Inc. v. Johnston, 295 F.2d 856 (4th Cir. 1961). On October 17, 1962 the NLRB, in a 3 to 2 ruling, reversed the Trial Examiner and ordered Darlington "to pay back wages to the discharged employees until they could obtain equivalent jobs, or until they are either put to work at an affiliated mill or put on a preferential hiring list for such employment." It also ruled that Deering Mrilliken was equally liable for the back pay and that it must reinstate the discharged workers if the 
ordered the Trial Examiner to hear evidence on TWUA's charge that Darling ton was controlled by Deering Milliken. ${ }^{14}$ During the next ten months, extenlsive evidence was taken at the remand hearing. In December 1959, more than a year after the remand hearings had closed, the Trial Examiner, noting that much time and effort had been fruitlessly expended, ${ }^{15}$ submitted a Supplemental Intermediate Report rejecting the Union's claim of a single employer status between Darlington and Deering Milliken, and recommended dismissal of the complaint against Deering Milliken. ${ }^{16}$ The case again came before the Board, but no action was taken until January 1961, over three years after the first remand order. The Board granted a motion of TWUA for a second remand to the Trial Examiner on the basis of newly discovered evidence relating to the alleged single employer status. ${ }^{17}$ The remand order, however, was not limited to consideration of the newly discovered evidence but also required further hearings and testimony covering

(2) the responsibility of Deering, Milliken \& Co., Inc., either for the unfair labor practices of Darlington Manufacturing Company or to remedy those unfair labor practices and (3) such further evidence as may be deemed proper and appropriate under the circumstances. ${ }^{18}$

Darlington mill is reopened. If it is not, they must be offered the first available jobs at the other mills held to be under Deering Milliken's control and Milliken is to pay all moving expenses of such employees. Darlington. Mfg. Co., 51 L.R.R.M. 1278 (1962).

14. 295 F.2d 856, 858 (4th Cir. 1961).

15. The Trial Examiner observed at the conclusion of the remand, "We have indecd labored but have brought forth not even a mouse." Id. at 859.

16. Ibid. Every opportunity was given TWUA to prove Deering Milliken's responsibility for Darlington's labor policy. Even at the conclusion of the remand hearings, at the request of the General Counsel, the record was held open in order that he and TWUA might review the evidence to make sure that sufficient available evidence to support the union's theory of a unitary organization had been offered. After the requested period latd passed without any effort on the part of the General Counsel or the union to offer additional or supplemental evidence, the record was closed. Ibid.

17. Ibid. The basis for this remand order was a public announcement by Deering Milliken that it had appointed a president for each of its three manufacturing divisions. (The three manufacturing divisions were its fine goods division, its worsted division, and its woolen division. It is to be noted that Darlington, a print cloth mill, did not fall into any of these three categories.) The union contended that this announcement was inconsistent with the company's earlier contention that it was not engaged in manufacturing activities since many of the particular mills listed in the three divisions were found in the etrlier hearings not to be under the control of Deering Milliken. Thus, the tunion argued (not knowing the existence of these "manufacturing divisions" prior to the newspaper reports), there was sufficient newly discovered evidence to reopen the case. See Brief for Appellant, pp. 7-8, Deering Milliken, Inc. v. Johnston, 295 F.2d 856 (4th Cir. 1961). Deering Milliken objected to the second remand on the basis that the events suggested by the press releases occurred four years after the Darlington mill had closed and furthermore that the announcement followed a merger of Deering Milliken with Cotwool Manufacturing Company. Sce Brief for Appellee, pp. 12-14.

18. 295 F.2d 856, 860 (4th Cir. 1961). It is to be noted that during the hearings of the previous remand there had been prolonged and extensive consideration of the supplemental question of possible remedies in the event an unfair labor practice should be found to have been committed. Id. at 858 . 
At this point Deering Milliken sued in the district court to enjoin the remand, asserting that the Board's action constituted an unreasonable delay in violation of sections $6(\mathrm{a})$ and $10(\mathrm{e})$ of the Administrative Procedure Act. The district court, in granting the injunction, held that the new hearings would cover issues already extensively considered and that the excessive delay would cause plaintiff irreparable injury. ${ }^{10}$ The Fourth Circuit, relying in part on the Administrative Procedure Act, upheld the jurisdiction of the district court to intervene but modified the injunction to allow further hearings respecting the newly discovered evidence. The court stated that:

the remainder of the Board's remand order is so unspecific and broad that it lends justification to the fears of the plaintiff ... that hearings lasting weeks and months and costing many thousands of dollars, may be required to replow the same ground covered in the hearings on the first remand. This, we think would impose undue additional delay in the light of the overly long pendency of these proceedings already, amounting to a failure to bring these proceedings to a conclusion with reasonable dispatch. To the extent, therefore, that the order of the District Court prohibits further hearings on the second remand directed to the issue occasioning the first remand, or any other unspecific matter, we think the District Court's action was justified by the record. ${ }^{20}$

Deering Milliken represents the first instance in which a court in dealing with the problem of delay has relied upon section $6(a)$ of the APA, requiring generally that agencies proceed with reasonable dispatch. ${ }^{21}$ It also represents one of those exceptional situations where a court has reviewed agency action during the course of administrative proceedings. In deciding whether a court should make such a determination, and, if so, under what circumstances, it is necessary to consider not only section $6(a)$ and its legislative history but also the rationale and scope of the long established judicial policy of avoiding premature review of agency action.

The insistence of courts upon timeliness of review is designed primarily to avoid premature review of administrative action and is based upon considerations of economy and a recognition of the proper role of courts in their relationship with the administrative process. By limiting review to "final" orders, courts protect both the parties and agencies from the additional financial burdens of piecemeal review, and preserve the time and efforts of the judiciary for other matters. Even more important, it is believed that premature review of agency action would encroach upon the policy making functions of administrative agencies. ${ }^{22}$ Administrative agencies, having the benefits of specialization and

19. Deering Milliken, Inc. v. Johnston, 193 F. Supp. 741, 744 (MF.D.N.C. 1961).

20. 295 F.2d 856, 869 (4th Cir. 1961).

21. Administrative Procedure Act $\S 6$ (a), 60 Stat. 240 (1946), 5 U.S.C. $\S 1005$ (a) (1958). This provision of $\S 6(a)$ includes the words "except that due regard shall be had for the convenience and necessity of the parties or their representatives."

22. Professor Davis defines the administrative agency as "a governmental authority, other than a court and other than a legislative body, which affects the rights of private parties through either adjudication or rule making." 1 Davis, ADsmistrantve LAv TREATISE $\$ 1.01$ (1958). The power of adjudication to which Davis refers is legislative in 
expertise and possessing broad investigatory powers, ${ }^{23}$ have greater calpacity and competence than courts to administer complicated regulatory legislation. Thus, there are considerable broad areas of delegated administrative discretion over which judicial review is limited. ${ }^{24}$ If courts intervene too early, the exercise of informed discretion and thus the advantages of the administrative process may be partially or completely foregone. For example, where a court decides that certain evidence should be excluded prior to a decision on the merits by the agency, not only is the outcome of a particular agency action likely to be affected but also such a decision itself necessitates a familiarity with the nature of the proceedings and the relationship of the evidence to it. A third reason for judicial nonintervention is the awareness that, if agencies are to play a responsible role in the administration of public policy, it will be necessary for them to work out many of their own problems by having the freedom to make and correct their own mistakes. ${ }^{25}$ These considerations are generally subsumed under the related, overlapping doctrines of ripeness, exhaustion, and finality, which govern the relationship between courts and other governmental institutions generally. ${ }^{26}$ The requirement of ripeness is based

nature and, to this extent, the agency is an initial policy maker. If a court prematturely reviews a controversy pending before an agency, it incorrectly usurps the agency's function.

23. Under its investigatory powers an agency has the power to subpoena witnesses and records. In short, the agency is an institution capable of performing in an area that the courts were not intended to enter. See Macauley v. Waterman S.S. Corp., 327 U.S. 540 (1946), and Comment, The Exhatstion of Administrative Remedics, 2 RACE REL. L. Rew. 561 (1957).

24. Section 10 of the APA which deals with judicial review is modified by the introductory clause "Except so far as ... agency action is by law committed to agency discretion. ..." For a discussion of action committed by law to agency discretion see 4 DAvis, ADMINISTRATIVE LAw TrEatise $\$ 28.16$ (1958).

25. Brandeis suggested this idea when he stated that "Responsibility is the great de" veloper of men." St. Joseph Stock Yards Co. v. United States, 298 U.S. 38, 92 (1936) (concurring opinion). Only with responsibility and a reasonable opportunity to correct its own errors will the administrative tribunal develop into the functional body it was chvisioned to be. As Judge Friendly observed in a lecture at Harvard, "the best agency to improve agency performance is the agency itself." Quoted in Address by Philip Elman, First Annual Corporate Counsel Institute, Northwestern University School of Latw, Oct. 11, 1962.

26. Both ripeness and exhaustion are part of the basic doctrine of the final order rule. This doctrine of finality is analogous to the policy against picce-meal review found in the judicial system, and is based on the common policy of avoiding constant delays in the course of proceedings by reviewing mere procedural requirements of interlocutory chituracter. See note 69 infra. The doctrine of ripeness was applied in Federal Power Commission v. Metropolitan Edison Co., 304 U.S. 375 (1938). In that case, the Supreme Court reversed a decree of the circuit court of appeals restraining the FPC from procectling with an investigation of Metropolitan's affairs until it disposed of objections to its jurisdiction raised by the latter's petition for a rehearing. The commission had grantcd the petition for a rehearing but had proceeded to hear evidence on other issues without ruling on it. The Court, finding that the question was premature and thus that the court of appeals was without jurisdiction to issue the decree, said that permitting judicial review of intermediate administrative orders would afford an "opportunity for constant delays in the course 
upon the principle that the judicial system should decide real or present rather than abstract or hypothetical issues and thus focuses upon the presence or imminence of harm to the complaining party from the government action.7 The exhaustion doctrine requires that a party have exhausted all the channels in the administrative process which might provide a remedy for his alleged injury and thus focuses upon whether something remains for resolution by the agency. ${ }^{28}$ Finality requires that there be a final decision rather than a tentative determination by the agency. ${ }^{29}$ Each of these doctrines relates to the problem of whether a petitioner seeking judicial assistance has prematurely resorted to the courts, and allows the courts to await the completion of the administrative process before reviewing alleged errors.

The application of these doctrines in any particular case is rendered uncertain by the fact that countervailing considerations may outweigh those that mitigate against early review of administrative action. The most important con-

of the administrative proceeding." Id. at 383. Frozen Food Express v. United States, 351 U.S. 40 (1956) and United States v. Storer Broadcasting Co., 351 U.S. 192 (1956).

The doctrine of exhaustion, as part of the doctrine of finality, is exemplified by National Lawyers Guild v. Brownell, 225 F.2d 552 (D.C. Cir. 1955). Here the plaintiff, a national bar association, brought suit to contest the Attorney General's proposal to designate plaintiff as a communist dominated organization. The court held in the absence of a showing of impending irreparable injury flowing from the delay incident to a pursuit of administrative remedies, the plaintiff must first exhaust those remedies available. But see Ieedom v. International Union of Mine, Mill \& Smelter Workers, 352 U.S. 145 (1956).

27. Although both ripeness and exhaustion relate to the proper timing of reviewwhen do you insert the court-ripeness focuses "upon the types of functions that courts should perform." 3 Davis, Adarinistrative Law Treatise $\$ 21.01$ (1958). It is this type of problem, raising issues of institutional capability, rather than that of exhaustion of remedies, which has most relevance to Deering Milliken and the problem of delay.

28. The doctrine of exhaustion of administrative remedies did not gain general recognition until 1908 in the case of Prentis v. Atlantic Coast Line Co., 211 U.S. 210 (1903). The case which has become a classic in the field of exhaustion, however, is the later decision of Myers v. Bethlehern Shipbuilding Corp., 303 U.S. 41 (1938). The Mfyers case arose when Bethlehem brought a bill in equity against the NLRB to enjoin it from holding a hearing on a complaint issued by the Board against Bethlehem. The district court granted the injunction and the court of appeals affirmed. The Supreme Court, in an opinion by Mrr. Justice Brandeis, reversed, however, referring to "the long settled rule of judicial administration that no one is entitled to judicial relief for a supposed or threstened injury until the prescribed administrative remedy has been exhausted." Id. at 50-51. This doctrine of exhaustion was well stated by the Court in Aircraft \& Diesel Equipment Corp. v. Hirsch, 331 U.S. 752 (1947). The plaintiff there sued for a declaratory judgment that the Renegotiation Acts were unconstitutional and for an injunction against the continuation of proceedings under these acts then pending in the Tax Court. The suit was held premature on the basis of failure to exhaust administrative remedies. The Supreme Court stated at 767:

The very purpose of providing either an exclusive or an initial and preliminary administrative determination is to secure the administrative judgment either, in the one case, in substitution for judicial decision or, in the other, as foundation for or perchance to make unnecessary later judicial proceedings.

29. See, e.g., Eastern Utilities Associates v. SEC, 162 F.2d 385 (1st Cir. 1947) ; Canadian River Gas Co. v. FPC, 110 F.2d 350 (10th Cir. 1940), cert. denicd, 311 U.S. 693 (1940). See also 4 DAVIS, op. cit. sitpra note 24 , at $\$ 28.12$. 
sideration here, of course, is the injury to a party resulting from denial of review at a particular time. Thus, where the jurisdiction of an agency to take a particular action may fairly be said to be in doubt and the jurisdictional question is based upon considerations that are not within the ambit of the agency's peculiar competence, courts have decided this issue before completion of the administrative proceedings. ${ }^{30}$ Similarly, where the agency clearly does not have the authority to grant the relief sought by the petitioner or to conduct an investigation, courts have granted immediate relief. ${ }^{31}$ Another instance of early review is where the constitutionality of a provision of the statute administered by the agency is challenged..$^{32}$ Here, however, other considerations, such as the possibility that the agency action will avoid the necessity of a constitutional decision or at least change the posture of the constitutional issue, may preclude review before the completion of the agency proceedings. ${ }^{33}$ Courts will also gen--

30. In the case of Nolan v. Fitzpatrick, 9 N.J. 477, 89 A.2d 13 (1952) (per Vanderbilt, C.J.), the court specifically refused to follow the $M y c r s$ doctrine of exhaustion and allowed review. In a suit by the Boulevard Commissioners to compel defendant Board to raise the total amount of the plaintiff's requisition, the court noted that

[In an earlier case] we recognized two exceptions in the interest of justice to the rule of exhaustion of remedies, the first where the jurisdiction of the statutory tribunal was questioned on persuasive grounds and the second where the statitory tribunal had jurisdiction but the charges asserted before it were so palpably defective that its jurisdiction was merely colorable.

Id. at $486,89 \mathrm{~A} .2 \mathrm{~d}$ at 17 . The court also went on to say that "the only result of requiring an exhaustion of administrative remedies where only a question of law is in issue would be useless delay, and this in the interest of justice cannot be countenanced." Id. at $487,89 \mathrm{A.2d}$ at 17 .

31. See, e.g., Union Pacific R.R. Co. v. Board of Co. Comm., 247 U.S. 282 (1918); Waite v. Macy, 246 U.S. 606 (1918).

32. The most notable exception to finality is probably where questions of constitutionality arise either as to the action of the administrative agency or as to the statute under which the agency works. There is, however, no clearcut line of demarcation in the cases to indicate when challenges to the constitutionality of statutes or of the agency action itsclf will be considered initially by the court without prior agency action. An: example of a casc which was reviewed before administrative action was complete is Parker v. Lester, 112 F. Supp. 433 (N.D. Cal. 1953), a case involving six merchant seamen who argued that the power of the Commandant of the Coast Guard to exclude scamen from employment on merchant vessels for "security reasons" was unconstitutional because it denicd due process of law. The court stated that "no special familiarity with complicated factual situations is necessary for the granting of relief; no administrative expertese [sic] comes into play, The issue, here, is one wholly of law. In short, the policy considerations which underlic judicial forbearance are inapplicable" Id. at 440 . An example, however, of a case in which a constitutional issue was raised unsuccessfully in what has been called "the current trend" is Allen v. Grand Central Aircraft Co., 347 U.S. 535 (1954). In this case a complaint was filed by the Wage Stabilization Board under the Defense Production Act. The action was challenged on the ground that the provisions of the act were unconstitutional. The Supreme Court declined to consider the challenge saying "it would be premature action on our part to rule upon... [it] until after the required administrative procedures have been exhausted." Id. at 553.

33. In the case where a party challenges action on the grounds that it is unconstitutional, the court is caught between the desire to correct the constitutional defect at the 
erally review where the action of the agency is such that unless a claim is immediately reviewed a party will suffer irreparable injury, i.c., no procedure is made available within the agency by which immediate and effective review and relief can be granted. ${ }^{34}$

The question of irreparable injury can be viewed in terms of whether, rather than when, relief will be granted. Since the alleged imminent injury is usually one which is not compensable, review must be granted immediately to avoid what may be an unjust deprivation. In Columbia Broadcasting Company v. United States, ${ }^{35}$ for example, the Supreme Court held that the plaintiff was entitled to review of a Federal Communication Commission regulation which, if applied, would deny a license to any broadcasting company which entered into certain defined types of contracts with any broadcasting networks. CBS claimed that this regulation would adversely affect its contractual relationships with broadcasting stations. The Court, per Chief Justice Stone, found that irreparable injury would be caused to CBS from "wholesale cancellation of its contracts," and that review of the order by the FCC would not be adequate, since such a proceeding "if ever instituted, which is uncertain ... would come

earliest point with the often prevailing desire not to decide constitutional issues unless absolutely necessary. See, e.g., Ashwander v. T.V.A., 297 U.S. 288 (1936). See also Bick:cl, The Supreme Court, 1960 Term, Foreword: The Passive Virtues, 75 HArv. L. REv. 40 (1961).

34. See, e.g., Algonquin Gas Transmission Co. v. FPC, 201 F.2d 334 (1st Cir. 1953). Algonquin applied for and received a certificate necessary to construct a pipe line system. It had nearly finished construction when the Court of Appeals, to which a competitor of Algonquin had petitioned for review of the order granting the certificate, vacated the order and remanded the case to the Commission for further proceedings. Algonquin then applied to the Commission for a temporary certificate. This request was denied. At this point Algonquin brought a petition for review of the Commissioner's order denying the certifiente for lack of jurisdiction. The First Circuit held it should be reviewed. If it were not, the court noted, the question would be moot. See also Atlantic Seaboard Corp. v. FPC, 201 F.2d 568 (4th Cir. 1953). For a general discussion of review in cases where the administrative action has not been completed see Davis, Administrative Remedies Ofters Necd Not be Exhausted, 19 F.R.D. 437 (1957).

35. 316 U.S. 407 (1942). A similar result was reached by the court in Levers v. Anderson, 326 U.S. 219 (1945), where the plaintiff's permit to operate a wholesale liquor business was annulled by the Alcohol Tax Unit of the Bureau of Internal Revenue.

The Court of Appeals dismissed plaintiff's appeal from the order of annulment because it had not applied to the Commissioner for reconsideration as was permitted by the Treasury Regulations. The Supreme Court reversed on the ground that the Mfyers rule did not automatically require that judicial review must be denied where rehearing was authorized but not sought. In reversing, the Court said that it is not necessary to observe "mere formalities which waste the time of litigants and tribunals, tend unnecessarily to prolong the administrative process, and delay or embarrass enforcement of orders which have all the characteristics of finality essential to appealable orders." Id. at 222.

This case was followed by a more lenient attitude by the courts where review was sought. The rule that one must exhaust his administrative remedies before he is entitled to judicial review was no longer held to operate automatically where relief is expressly permitted by statute. This flexible approach has since been labeled the "discretionary approach." See Comment, The Exhaustion of Administrative Remedies, 2 RACE REL. L. REP. $561,564-65$ (1957). 
too late to save appellant from the injury wrought by the outlawry of its contracts." 36 "The ultimate test of reviewability," the Court continued, "is not to be found in an overrefined technique, but in the need of the review to protect from the irreparable injury threatened in the exceptional case by administrative rulings which attach legal consequences to action taken in advance of other hearings and adjudications that may follow, the results of which the regulation purports to control."37 Other instances in which threatened irreparable injury has justified immediate judicial review are where an agency has granted or denied a motion to change the time or place of the hearing on grounds of "forum non conveniens"38 and where an agency has demanded disclosure of information over the objection of a party that such information is privileged or confidential.39

36. 316 U.S. 407, 423-24 (1942).

37. $I d$. at 425 .

38. See Jeffries v. Olesen, 121 F. Supp. 463 (S.D. Cal. 1954), a "forum non conveniens" case, where the court held that the Post Office Department denied due process by holding a hearing in Washington instead of in Los Angeles. The court stated that "It is equally shocking to learn that an administrative tribunal has so disregarded the necessity and convenience of a party defendant in an administrative proceeding." Id. at 476.

Compare, however, Eastern Utilities Association v. SEC, 162 F.2d 385 (1st Cir. 1947), where Eastern Utilities, the plaintiff, sought to move the SEC hearing from Philadelphia to Boston, because the offices of the witness for the hearing and the stockholders of Eastern were in Boston. Although the situation was such that the injury sought to be avoided would be irreparable if the case were not reviewed at this point, the court refused to review. Professor Davis characterized this situation as follows:

No matter what a court in reviewing a final order might think of the Commission's order denying a change in the place of hearing, the Court would be powerless to restore to the petitioner the expense and inconvenience of attending the hearing in Philadelphia. The result was therefore a total denial of review on the issue of the place of the hearing.

Davis, supra note 34 , at 465.

39. See, e.g., Boyd v. United States, 116 U.S. 616 (1886) (violated privilege against self-incrimination); Hale v. Henkel, 201 U.S. 43 (1906) (subpoena is unduly vague or unreasonably burdensome). For a more complete discussion of the role of the court in proceedings to enforce administrative demands of disclosure of information, see Brief for the Respondent, pp. 17-18, Endicott Johnson Corp. v. Perkins, 317 U.S. 501 (1943) as qutoted in Gellhorn \& Byse, Administrative Law 579 (1960). See also 1 Davis, op. cit. silpra note 22 , at $\S \S 3.11-.12$.

Still another situation in which courts have found irreparable injury is exemplificd by Isbrandtsen Co. v. United States, 211 F.2d 51 (D.C. Cir. 1954), cert. denicd, 347 U.S. 990 (1954). The case concerned an association of eighteen common carrier steamship lines, which had agreed that any shipper who refused to use conference lines exclusively would be charged rates higher than those who agreed. Isbrandtsen, the only non-member line competing with the conference vessels, immediately filed a complaint with the Federal Maritime Board. The Board, without hearing, issued an order permitting dual rate systems temporarily, and denied Isbrandtsen's request for an immediate hearing. At this point Isbrandtsen appealed to the D.C. Circuit Court of Appeals which allowed review, stating that the Board, by its actions

virtually removed Isbrandtsen from the shipping market involved. Whether this removal was temporary or permanent, Isbrandtsen would inevitably suffer "real, immediate and incalcuable" harm.

Id. at 56 . 
Most of the cases of irreparable injury justifying immediate judicial relief present peculiar fact situations and thus few generalizations about when review is available can be derived from them. However, against this background of case law, it can be seen that inordinate delay, as exemplified by Decring MIilliken, provides a new illustration of irreparable injury which can occur unless a court grants immediate review. The injury a party must bear as a result of delay may be viewed in terms of cost, since numerous costs are directly related to the length of a judicial or administrative proceeding. ${ }^{10}$ Perhaps the most substantial cost is produced by the process of litigation itself. 11 The number of man-hours of lawyers, executives, technicians, and other corporate employ'ees participating in a hearing can entail incredibly high costs. Another significant cost resulting from delay is due to the continuing uncertainty as to the outcome of the case. The possibility of an unliquidated financial liability may adversely affect the credit position of a corporation during the litigation as well as the market price of its stock. ${ }^{42}$ And where liability continues to accrue daily during the course of the litigation, as in the Dcering Milliken case, the absence of a final determination prevents a party from mitigating his loss. ${ }^{43}$

Although any delay in administrative proceedings imposes these costs upon a party, a judicial determination to relieve a party of such hardships in a particular case must rest upon a consideration of the cause of delay and the effect relief will have upon the proper functioning of the administrative process. Delay in administrative proceedings may take either the form of an endless series of hearings without a final decision ${ }^{44}$ or a refusal by an agency to act on

40. Landis, supra note 3 .

41. If the NLRB found Deering Milliken responsible for the unfair labor violation (as it ultimately did, supra note 13) the corporation would have been liable for potential backpay liability accruing at a rate in excess of $\$ 100,000$ a month. Brief for Appellee, p. 46. Without doubt this affects not only the credit position of Deering Mfilliken, especially through its effect on the stock value, but also, if a liability reserve is created, the book value and reported income.

42. Deering Milliken's liability because of the six year delay in the final determination of the unfair labor charge is expected to "run into the millions of dollars." Charlotte News, Oct. 19, 1962, p. 1-B, cols. 1-2.

43. In the Deering Milliken case, for example, the defendants had, preparatory to the hearings on the first remand, made available for inspection 10,000 pages of records and documents, of which 2600 pages were selected by the General Counsel for further analysis. Fourteen witnesses testified, over 400 pages of exhibits were introduced, and over 2500 pages of testimony taken. The cost and expense of making available just one of these exhibits was alleged to have required nearly 400 manhours of work by employees of Deering Mfilliken. 295 F.2d 856, 858 (4th Cir. 1961). This cost to Deering Milliken would have been substantially augmented by the second remand where it was estimated that it would require approximately an additional 62,000 pages of testimony and 13,000 pages of exhibits. Bricf for Appellee, p. 45.

The cost of consuming the time of regular employees, it can be noted, can be measured either in terms of the direct outlay for employees' services or the return from alternative employment which the corporation must forego.

44. Delay which is characterized by an endless series of hearings results from one of two causes. One such cause is where a party in a superior position is deliberately stalling 
a matter before it. ${ }^{45}$ When the latter form of delay results from a lack of adequate resources, courts should be extremely reluctant to order an agency to decide a particular case. ${ }^{46}$ Granting such relief to one litigant will necessarily cause further delay for others. But where an agency refuses to decide a particular case for some other reason ${ }^{47}$ or for no reason at all, relief in the form of a mandatory injunction would seem appropriate.48 Indeed, the Supreme Court, in Smith v. Illinois Bell Telephone Co., ${ }^{40}$ held that the refusal of a state public ultilities commission to decide the company's request for a rate change justified the intervention of a federal court to enjoin the enforcement of previously established, and allegedly confiscatory, rates. ${ }^{50}$ The problem of whether

because delay works to his advantage. Thus it has been noted by Judge Prettyman, supra note 2 , at 970 , that

Inexplicable delays and expense are due to the wily lawyer with a weak case rather than the incompetence of counsel. The former is attempting to create all possible confusion so as to delay to the bitter utmost the inevitable bad tidings.

There is some hint by the Fourth Circuit that such may have been the case in Deering Milliken: "[h]ere the Union has asked for additional hearings and could hardly complain of the resulting delay but the employer has not asked for them and is entitled to question their reasonableness." 295 F.2d 856, 868 (4th Cir. 1961).

A second cause of this type of delay is where the administrative agency is unduly slow and cumbersome in its proceeding. Such was the case in Deering Milliken where the supplemental issues covered by the second remand, had previously been extensively preparcd and tried in a protracted hearing, lasting over two years. 1d. at 858.

45. See, e.g., Addison v. Holly Hill Fruit Products, 322 U.S. 607 (1944), a stit for wages under the Fair Labor Standards Act, where the Court required the Wage and Hour Administrator to promulgate his definition of "area of production" under the act, a definition which was crucial to the issue in the case. The Court noted that the district court would not be telling the administrator how to exercise his discretion, but would merely require him to exercise it, noting that this was a judicial remedy against inaction. See International Ry. Co. v. Prendergast, 52 F.2d 293 (1930).

46. See note 6 sipra and accompanying text.

47. It has even been suggested by one commentator that "delay is a weapon which can be, and has been, used by an agency to exhaust private parties." Oulahan, stpra note 2 , at 120.

48. The power of a court to grant injunctive relief against an agency where there is a showing of great or irreparable injury has been successfully invoked on general equitable principles in a number of cases. In American Federation of Labor v. Madden, 33 F. Supp. 943 (D.D.C. 1940), for example, a motion to dismiss on the ground of lack of jurisdiction, was overruled by the court which held that a sufficient showing of great and irreparable injury had been made to sustain an independent suit in equity. See also, Farmer v. United Electrical Workers, 211 F.2d 36 (D.D.C. 1953), cert. denied, 347 U.S. 943 and Klein v. Herrick, 41 F. Supp. 417 (S.D.N.Y. 1941).

49. 270 U.S. 587 (1926).

50. In the Smith case the Court noted that "the commission, for a period of two ycars, remained practically dormant; and nothing in the circumstances suggests that it had any intention of going further with the matter." Id. at 591. The Supreme Court, in holding that petitioner was entitled to judicial review, stated further, that

For this apparent neglect on the part of the commission, no reason or excuse has been given; and it is just to say that, without explanation, its conduct evinces an entire lack of that acute appreciation of justice which should characterize a tribunal charged with the delicate and important duty of regulating the rates of a public 
delay results from an overcrowded docket or from wilfulness on the part of an agency is not present where delay takes the form of unduly slow and cumbersome procedures. Here, however, courts must consider the possibility of infringement upon agency discretion. Agencies have traditionally been vested with considerable discretion to determine their own evidentiary and procedural rules. ${ }^{51}$ The complex, specialized type of findings which must often be made in administrative hearings strongly suggests that courts continue to grant considerable deference to agency procedures and refrain from automatically applying to agencies the traditional standards used in invalidating delay in judicial proceedings. ${ }^{52}$ Thus, ordinarily an agency decision to take further evidence on an issue already considered should prevail, for such a determination will frequently involve that specialized competence which an agency is presumed to possess. ${ }^{53}$ But these considerations underlying nonintervention do not ineluctably outweigh the interests of a party subjected to burdensome extensive proceedings. Where an agency continues hearings to the point where they appear "repetitive, purposeless and oppressive," ${ }^{\prime \prime}$ the burden should be on the agency

utility with fairness to its patrons, but with a hand quick to preserve it from confiscation. Property may be as effectively taken by long-continued and unreasonable delay in putting an end to confiscatory rates as by an express affirmance of them; and where, in that respect, such a state of facts is disclosed as we have here, the injured public service company is not required indefinitely to await a decision of the rate-making tribunal before applying to a federal court for equitable relief.

Id. at 591-92.

51. The adjudicatory procedures of the administrative agencies stem primarily from their own made rules and customs. See § 3(a) of the APA, 60 Stat. 243 (1946), 5 U.S.C. $\S 1002$ (a) (1958). There is no basic procedural pattern which all agencies follow and the role of the courts in the formulation of administrative procedure is limited to situations of abuse of this discretion, generally the enforcement of constitutional and statutory requirements. See 1 Davis, op. cit. supra note 22, at $\S \S 8.01-.03$, and Federal Communications Commission v. Pottsville Broadcasting Co., 309 U.S. 134 (1940), the often cited decision that courts must not transplant judicial practices to the administrative process.

52. The difficulty in applying a set of mechanical rules of when to and when not to intervene in the administrative process was recognized by the court in Decring Ailliken. It said that

There are no absolute standards by which it may be determined whether a procecding is being advanced with reasonable dispatch. What is reasonable can be decided only in the light of the nature of the proceedings and the general and specific problems of the agency in discharging its functions and duties.

295 F.2d 856, 867 (4th Cir. 1961). This same conclusion was reached by the Supreme Court in Dickinson v. Petroleum Conversion Corp., 338 U.S. 507 (1950). The Court said in spealing of the mixed precedent on the subject of the finality of decrees:

This lamentation is equally fitting to describe the intervening struggle of the courts; sometimes to devise a formula that will encompass all situations and at other times to take hardship cases out from under the rigidity of previous declarations; sometimes choosing one and sometimes another of the considerations that always compete in the question of appealability, the most important of which are the inconvenience and costs of piecemeal review on the one hand and the danger of denying justice by delay on the other.

338 U.S. at 511.

53. See note 23 supra and accompanying text.

54. Deering Milliken, Inc. v. Johnston, 295 F.2d 856, 868 (4th Cir. 1961). 
to adduce a reason for taking evidence on an issue already heard or for ordering further hearings on such issues. Thus the Court of Appeals in Decring Milliken seems correct in reversing the district court and allowing a hearing on newly discovered evidence and prohibiting new hearings on isstes that were already heard. ${ }^{55}$ Except for the discovery of new evidence, the agency offered no explanation to justify its broad remand order. ${ }^{50}$ It is true that in making this type of determination the court substitutes its judgment for that of the agency. But this would not seem beyond the proper scope of the judicial process, since the question when agency procedures unduly infringe upon private rights concerns those broader aspects of the legal order for which coturts are primarily responsible..$^{57}$

Authority for curtailing the Board's remand order in Deering Milliken was found in section $6(\mathrm{a})$ of the APA, which provides that "Every agency shall proceed with reasonable dispatch to conclude any matter presented to it except that due regard shall be had for the convenience and necessity of the parties or their representatives." 58 The use of section $6(a)$ is significant, for prior to Deering Milliken it had not been used as the basis for an injunction, 50 although one court had stated in a strong dictum that section $6(a)$ could be enforced by a "mandatory injunction."

55. Ibid.

56. Id. at 860 .

57. For a discussion of the types of legal questions which courts make and the problem of the substitution of judicial judgment see 4 DAvis, op. cit. supra note 24 , at $\$ \S 30.01$ .06 .

58. 60 Stat. 240 (1946), 5 U.S.C. $\S 1005$ (a) (1958).

59. Not only has $\$ 6$ (a) not been used by the courts for enjoining unduly protracted proceedings but it has not even been used by the agencies to guarantee a party catught in the administrative process a hearing with dispatch. Illustrative is a decision of the Civil Aeronautics Board in National Airlines, Inc., Mail Rates, 18 C.A.B. 442 (1954). Here the Bureau Counsel of the $\mathrm{CAB}$ appealed from an order permitting evidence on the question of whether there had been unjustified or unwarranted delay in processing National's mailrate petition. National argued that $\S 6(a)$ of the APA, when violated by dilatory if not deliberate delay, and $\S 406$ of the Civil Aeronautics Act, which empowers the Board to "fix and determine a fair and reasonable rate of mail compensation," when read together, authorize the Board, on the basis of delay, to set its final rate at an earlier date than normal. The Board rejected this argument saying that "section 406 of the Civil Aeronatics Act may not be used directly or indirectly as a means of redress for violations of section 6 of the Administrative Procedure Act." Id. at 444. To this conclusion came the following words of dissent:

[T] he majority decision [is] ... in error on the following grounds :

1. It violates the spirit and intent as well as the letter of the Administrative Procedure Act which was designed to protect the rights of litigants against unduc or unwarranted delay in administrative proceedings.

2. The effect of the majority decision is to place National Airlines (and any other carrier who may now or in the future be in a similarly unenviable position) with no remedy for possible Board misfeasance in its mail-rate program.

3. The majority decision is contrary to sound public policy. Id. at 445 .

60. Atlantic \& Gulf Stevedores, Inc. v. Donovan, 274 F.2d 794 (5th Cir. 1960). The 
a party's contention that an agency proceeded with excessive haste. ${ }^{B 1}$ But, as one commentator has characterized section $6(\mathrm{a})$, "Few provisions of [the APA] have proved more useless in securing speedy and fair administrative justice."62

The legislative history of section 6(a) is ambiguous as to whether it requires agencies to avoid delay resulting from prolonged proceedings. The House Committee Report states:

The requirement that agencies proceed "with reasomable dispatch to conclude any matter presented" means that no agency shall in effect deny relief or fail to conclude a case by mere inaction, or proceed in dilatory fashion to the injury of the persons concerned. No agcncy should permit any person to suffer consequences of unwarranted official delay. ${ }^{03}$

court in a proceeding to require a deputy commission to proceed to a decision in a matter properly before him under the Longshoremen's Compensation Act, 33 U.S.C. $\$ 901-40$ (1958), reversed the district court holding that the Longshoremen's Act imposed a duty to hold a suitable hearing to pass upon and adjudicate all complaints raised. It went on to note in dictum that:

The APA provides categorically that "every agency shall proceed with reasonable dispatch to conclude any matter presented to it..." Apparently in recognition that a failure or refusal to hear and decide could be as destructive as bad deciding, Congress provided in $\$ 10(\mathrm{e})$ that Courts may review the inaction of an agency and specifically "compel agency action unlawfully withheld or unreasonably delayed." And enforcement may be by a mandatory injunction.

Id. at 802 .

61. Dolcin Corp. v. FTC, 219 F.2d 742 (D.C. Cir. 1954). This was a review of a cease and desist order of the FTC. The petitioners were engaged in the manufacture of a drug "Dolcin" designed primarily to relieve the symptoms of arthritis and rheumatism. Dolcin made far-reaching claims which resulted in an FTC complaint. After extensive hearings the trial examiner found Dolcin's claim unwarranted. In affirming this decision the revieving court remarked:

It may be that petitioners were in some degree prejudiced by the course the Commission took: their oral argument was delivered under the handicap of a fresh precedent rendered on the same medical evidence. But administrative agencies are under congressional mandate to "proceed with reasonable dispatch to conclude any" matter presented. ..."

Id. at 746 .

62. Oulahan, stpra note 2 , at 120 . This observation is substantiated by a number of cases which have arisen since the passage of the APA where delay was crucial but instead of finding relief for the complaining parties under the APA federal courts have intervened and compelled action on the basis of "general equitable principles." One such case is American Broadcasting Co. v. FCC, 191 F.2d 492 (D.C. Cir. 1951), an appeal from two orders of the FCC granting special service authorization to a broadeasting company. In compelling the FCC to finish proceedings which had been pending for six years, the Court of Appeals stated:

[O]n occasion the courts must act to make certain that what can be done is done. Agency inaction can be as harmful as wrong action. The Commission cannot, by its delay, substantially nullify rights which the [Federal Communication] Act confers ....

Id. at 501. See also, Panama Canal Co. v. Grace Line, 356 U.S. 309, 318 (1958) and Addison v. Holly Hill Fruit Products, 322 U.S. 607 (1944).

63. Senate Comm. on Judiciary, Administrative Procedure Act: Legislative History, S. Doc. No. 248, 79th Cong., 2d Sess. 264 (1946) (emphasis added). 
This statement clearly indicates that action as well as inaction could constitute "unwarranted official delay." But the Senate Committee Report states that "the requirement, that agencies proceed 'with reasonable dispatch to conclude any matter presented' is a statement of legal requirement that no agency shall in effect deny relief or fail to conclude a case by a mere inaction." 4 This langunge is reasonably subject to the interpretation that the provision addressed itself exclusively to requiring the agency to order hearings, or, following hearings, to render a decision within a reasonable time.

Such an interpretation seems erroneous, however. In construing the scope of section 6(a), it should be read in conjunction with section 10 of the act, which involves the type of administrative action that is reviewable and the scope of judicial review. Section 10(a) grants the right of review to "any person suffering legal wrong because of any agency action. ..."0r Section 10(c) states that "every final agency action for which there is no other adequate remedy in any court is subject to judicial review." reports state that " 'Final' action includes any effective agency action for which there is no other adequate remedy in any court." "final" seems appropriate in light of the judicial application of the finality concept before the enactment of the APA and the implications of other provisions of the APA relating to finality. As observed above, courts have found agency action to be "final" where such action threatens a party with imminent injury which would be irremediable at a later proceeding. Furthermore, section 10 (e) (A) requires a court to "compel agency action unlawfully withheld or unreasonably delayed"; $; 8$ if the definition of "final agency action" under section 10 (c) were limited to ultimate termination of agency proceedings, courts could never take the action authorized in section $10(\mathrm{e})$. Thus, "final agency action" for purposes of entitling a party to review must include any agency behavior which irreparably injures a party. ${ }^{69}$ The power to review agency action necessarily

64. S. Doc. No. 248, 79th Cong., 2d Sess. 205 (1946).

65. 60 Stat. 243 (1946), 5 U.S.C. \& 1009 (a) (1958).

66. 60 Stat. 243 (1946), 5 U.S.C. $\$ 1009$ (c) (1958).

67. S. Doc. No. 248, 79th Cong., 2d Sess. 213, 277 (1946). The House Report adds the adjective "operative" so that the statement reads "effective or operative agency action ..." This addition, however, does not change the meaning.

68. 60 Stat. 243 (1946), 5 U.S.C. $§ 1009$ (e) (A) (1958).

69. The conclusion that Congress intended "final agency action" to entitle a party to review when injured by unreasonable delay is strengthened when the statutes governing similar problems within the federal judicial system are examined. In the judicial process, as in the administrative process, there is an historic policy, whether at law or equity, for finality in court proceedings before an appeal is allowed. As Mr. Justice Frankfurter has observed in noting the policy behind finality:

Finality as a condition of review is an historic characteristic of federal appellate procedure. It was written: into the first Judiciary Act and has been departed from only when observance of it would practically defeat the right to any revicw at all. Cobbledick v. United States, 309 U.S. 323, 324-25 (1940). See 6 MLooke, Federal Practick II 54.04, at 22 (2d ed. 1953).

This policy of federal appellate review is presently embodied in Federal Rule 54, the final judgment rule. There is, however, a competing principle or qualification to prac- 
implies the power to reverse, modify, or set aside aspects of such action which violate an applicable legal rule or principle of justice. Thus, unduly prolonged proceedings, as well as an agency refusal to act, is subject to judicial invalidation. Once it is recognized that lengthy administrative proceedings are subject to review, the broad standard for invalidating agency action can be found in section $10(\mathrm{e})$ which requires courts to compel agency action unreasonably delayed and to set aside agency action "found to be (1) arbitrary, capricious, an abuse of discretion, or otherwise not in accordance with law ... [or] without observance of procedure required by law."T0 Thus, it need not be argued that section 6 (a) specifically confers upon a private party a right to compel an agency to "proceed with reasonable dispatch to conclude any matter presented to it ..."'71 for section 10 of the APA provides sufficient authority to enjoin or compel agency action for the protection of private parties. In determining whether action is "unreasonably delayed," "arbitrary," and not "in accordance with law,"72 however, the general duty imposed upon agencies under section 6 (a) clearly seems relevant.

tically every judicial principle of finality our court system has. 6 A foore, Federns Practice II 54.04, at 23 (2d ed. 1953). Such qualifications come in the form of prerogative writs, now combined in the All Writs Statute (28 U.S.C. $\$ 1651$ ), which have been necessary to give the system the flexibility it needs in exceptional situations where appellate reviev would not be available under either the statutes governing interlocutory appeals (28 U.S.C. $\$ 1292$ ) or those governing appeals from final judgments (2\$ U.S.C. $\S 1291$ ). The purpose of this statute is to enable an appellate court to review a decision by an appropriate prerogative writ, when the claims of the individual case that justice demands a present review outweigh the general policy which confines appeals to final orders. Determining when circumstances justify immediate review, as in the administrative process, is a problem of balancing. Mrere inconvenience or the expense that will result from a postponed review is usually not sufficient to warrant the issuance of a writ. Where extreme hardship or questions which do not lend themselves to decision on appeal from a final judgment at a later time because the issue will be moot or the complaining party irreparably injured, are involved, however, reviev is usually permitted. Id. at 71. Forum non conveniens is one such example and, to quote Professor Moore, so is the situation where review will be postponed because of an order for a new trial following "perhaps a long and expensive second trial. . . " 6 Afoone, Feorrar Practice If 59.15[2], at 3901 (2d ed. 1953). Although there are many basic difierences between the administrative process and the judicial system it is accurate to say that if the Deering Milliken situation were transposed to the federal courts, an appellate court could assume jurisdiction. Once jurisäiction was assumed a federal appeliate court, under the general supervisory power that it has over lower federal courts, could circumseribe the action of the trial court in the case of inordinate delay. From this result it may be argued that since Congress gave the federal courts the power to remedy the type of problem found in "Deering Milliken, in reviewing other courts, it intended the "final agency action" of $\$ 10$ (c) of the APA to grant similar powers in the area of administrative process.

70. 60 Stat. 243 (1946), 5 U.S.C. \$ 1009 (e) (B) (1958).

71. 60 Stat 240 (1946), 5 U.S.C. \$ 1005 (a) (1958).

72. 60 Stat. 243 (1946), 5 U.S.C. $\$ 1009$ (e) (1958). 